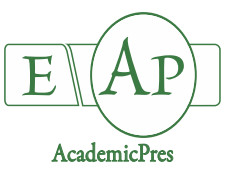

Glišić RM et al. (2021)

Notulae Botanicae Horti Agrobotanici Cluj-Napoca

Volume 49, Issue 2, Article number 12180

DOI: $10.15835 /$ nbha 49212180

Research Article

\title{
Phytoaccumulation of metals in three plants species of the Asteraceae family sampled along a highway
}

\author{
Radmila M. GLIŠIĆ ${ }^{1 *}$, Zoran B. SIMIĆ2 , Filip J. GRBOVIĆ ${ }^{1}$, \\ Vera R. RAJIČIĆ ${ }^{3}$, Snežana R. BRANKOVIĆ ${ }^{1}$ \\ ${ }^{1}$ University of Kragujevac, Faculty of Science, Department of Biology and Ecology, Radoja Domanovića 12, Kragujevac, Republic of \\ Serbia; radmila.glisic@pmf.kg.ac.rs (*corresponding author);filip.grbovic@pmf.kg.ac.rs; snezana.brankovic@pmf.kg.ac.rs \\ ${ }^{2}$ University of Kragujevac, Faculty of Science, Department of Chemistry, Radoja Domanovića 12, Kragujevac, Republic of Serbia; \\ zoran.simic@pmf.kg.ac.rs \\ ${ }^{3}$ University of Niš, Faculty of Agriculture, Kosančićeva 4, 37000 Kruševac, Republic of Serbia; verarajicic@yahoo.com
}

\begin{abstract}
The aim of this study was to determine the ability of roots and above-ground parts of three plant species of the Asteraceae family (Matricaria inodora L., Achillea millefolium L., Crepis setosa Haller fill.) for bioaccumulation and translocation of eight metals ( $\mathrm{Ca}, \mathrm{Mg}, \mathrm{Fe}, \mathrm{Mn}, \mathrm{Cu}, \mathrm{Zn}, \mathrm{Pb}, \mathrm{Cr}$ ). Those plants were sampled directly along the lanes of the highway at the entrance into the City of Kragujevac, Republic of Serbia. The investigated metals are emitted into the air from road traffic and are deposited in the surrounding soil. Many of them are toxic to the living organism, and it is, therefore, necessary to apply effective, economical, sustainable methods for their removal from the environment. An example of such a method is as phytoremediation, based on the use of metal hyperaccumulator plants. The results of this research showed the species studied differ in the absorption, translocation and accumulation of investigated metals. They also showed that species $M$. inodora and $A$. millefolium (leaves) can be used for the phytoextraction of $\mathrm{Ca}, \mathrm{Mg}, \mathrm{Fe}$, $\mathrm{Mn}, \mathrm{Cu}, \mathrm{Zn}$ and $\mathrm{Cr}$, species $C$. setosa (leaves) for $\mathrm{Ca}, \mathrm{Mg}$ and $\mathrm{Cu}$ species $M$. inodora (stem) for $\mathrm{Cr}$. The results further indicate that all three species absorb $\mathrm{Zn}$ from the soil and translocate it to the stems and leaves. All three of the studied species are suitable for phytostabilization of soils loaded with $\mathrm{Zn}$, but only the species $M$. inodora and $C$. setosa can be applied in phytoremediation of this metal.
\end{abstract}

Keywords: metals; phytoaccumulation; phytoremediation; plants; translocation

\section{Introduction}

The last two decades have been marked by intense urbanization and industrialization associated with extensive use of various transport means, which led to an increase in environmental pollution. Road traffic is one of the most significant contributors to the emission of high concentrations of different pollutants, including heavy metals that are primary pollutants in urban areas (Swaileh et al., 2004; Johanssona et al., 2009; Jankowski et al., 2015; Malinowska et al., 2015).

The exhaust gases of motor vehicles, tyre and road abrasion, wear of brake linings and of moving engine parts, corrosion of various vehicle components, catalytic converters and lubricating oils could all cause elevated

Received: 05 Dec 2020. Received in revised form: 20 Mar 2021. Accepted: 16 Apr 2021. Published online: 29 Apr 2021.

From Volume 49, Issue 1, 2021, Notulae Botanicae Horti Agrobotanici Cluj-Napoca journal uses article numbers in place of the traditional method of continuous pagination through the volume. The journal will continue to appear quarterly, as before, with four annual numbers. 
heavy metal content in roadside areas (Falahi-Ardakani, 1984; Horner, 1996; Gualtieri et al., 2005; Hjortenkrans et al., 2007).

Heavy metals are generally defined as naturally occurring metals and metalloids with a high atomic weight and high specific density, which is five times greater than that of water; above $5 \mathrm{~g} / \mathrm{cm}^{3}$ (Hawkes, 1997; Timothy and Williams, 2019). The most common heavy metals are lead (Pb), nickel (Ni), chromium $(\mathrm{Cr})$, cadmium $(\mathrm{Cd})$, arsenic $(\mathrm{As})$, mercury $(\mathrm{Hg})$, zinc $(\mathrm{Zn})$ and copper $(\mathrm{Cu})$. They are non biodegradable and tend to bioaccumulate. Many of them are toxic to the living organism (for example $\mathrm{Zn}, \mathrm{Ni}, \mathrm{Cu}, \mathrm{Co}$, As and $\mathrm{Cr}$ ). If they are present in excess, even those considered as essential induce oxidative stress and promote disease in humans (Jarup et al., 2003; Jaishankar et al., 2014).

Resuspension of metals in the air along the roads is the main source of pollution of the soil and vegetation near them. Emissions of pollutants from the traffic remain in the air for a long time, and later settle in soil and vegetation along the roads. They become available to plants directly by rain washing the dust off the road. Plants absorb them from the soil by their root system. This is the way pollutants enter the food chain and reach animals and humans. Heavy metals can also be harmful to the roadside vegetation as they could lead to reduction in growth and yield, as well as in their properties by changing physiological and biochemical processes. For example, chlorosis, leaf necrosis, discoloration or decrease in protein content may occur (Doğanlar and Atmaca, 2011; Kandziora-Ciupa et al., 2013).

Farmlands located near highways are exposed to elevated concentrations of different pollutants originating from the road traffic (among them are heavy metals) that can contaminate the crops. Some research has been conducted to determine their distribution related to the distance from the roads (Birch and Scollen, 2003; Malinowska et al., 2015).

Soil contamination by heavy metals presents a worldwide environmental issue, which requires continuous monitoring of the level of their content in the soil and finding methods for their removal. As previously said, one of them is phytoremediation; environmentally friendly, low-cost technique based on the use of metal hyperaccumulator plants (Laghlimi et al., 2015). These plant species are highly tolerant of heavy metals and therefore have the ability to grow and develop in metalliferous soils (Boonyapookana et al., 2005). The ability of plants to tolerate and accumulate metals in their roots can be applied in phytostabilization, which is an effective method for reduction of pollutants' migration in the soil, preventing their penetration into groundwater and various food chains (Susarla et al., 2002). Furthermore, their ability to accumulate metals in their organs can be used for monitoring of soil contamination by identifying their presence and quantity in it (Malizia et al., 2012). Successful remediation depends on properly selected plants with a great capacity for accumulation of certain metals.

This study has been undertaken to determine the content of some metals in the soil and various organs of the three species from the Asteraceae family, which were sampled along the highway at the entrance into the city of Kragujevac (Republic of Serbia). Those wild plants were chosen because of their abundance and great cover along the road. The purpose of the research was to establish the examined plants' ability of accumulation and translocation of the mentioned metals, and the possibility of their application as bioindicators and biomonitors of environmental conditions, but also in phytoremediation.

\section{Materials and Methods}

\section{Description of the study site}

The city of Kragujevac is located in the central part of the Republic of Serbia, with coordinates $\mathrm{N} 44^{\circ}$ 22 'and E $20^{\circ} 56^{\prime}$. The plant material studied has been collected using appropriate accessories, on ten sites, at a distance of $1 \mathrm{~m}$ from the edge of the road, along the section of the Batocina-Kragujevac highway, at the entrance into the city of Kragujevac (Figure 1). 


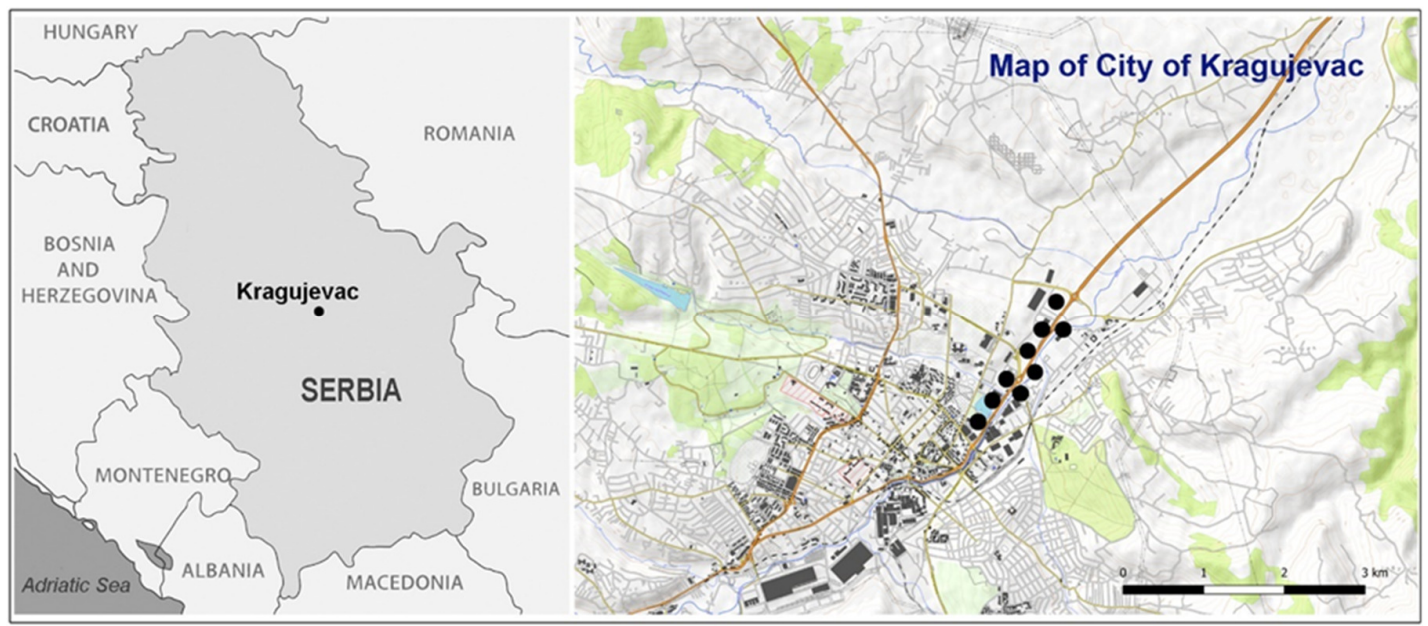

Figure 1. Geographical position and distribution map of the investigated area, according to QGIS 3.16.0 (black dots on the map indicate sampling sites)

\section{Experimental procedures}

The plant samples (whole plant, leaf, stem and root) of three species (Matricaria inodora L., Achillea millefolium L. and Crepis setosa Haller fill.), were taken from the sites of their greatest number and cover. They were identified by standard keys for the determination of plants: Jávorka and Csapody (1979), Josifović (1970) and Flora of Europe (1964-1980), in the laboratory of the Department of Biology and Ecology, at the Faculty of Science in Kragujevac.

The soil samples ( $2 \mathrm{~kg}$ each) were first air-dried and sieved through a $2 \mathrm{~mm}$ sieve. Smaller samples of $10 \mathrm{~g}$ weight were re-sieved. After drying and grinding of plant and soil samples $\left(24 \mathrm{~h}\right.$ at $105{ }^{\circ} \mathrm{C}$, Binder/Ed15053), a certain quantity of prepared material ( $3 \mathrm{~g}$ of soil and $2 \mathrm{~g}$ of plant material) was measured by the analytical scale, and then a standard procedure for preparing samples for chemical analysis (Branković et al., 2013) was performed.

In the soil and plant samples (root, stem, leaf, whole plant), the concentrations of metals $(\mathrm{Ca}, \mathrm{Mg}, \mathrm{Fe}$, $\mathrm{Mn}, \mathrm{Cu}, \mathrm{Zn}, \mathrm{Pb}$ and $\mathrm{Cr}$ ) were determined in the Department of Chemistry, at Faculty of Science in Kragujevac, using the atomic absorption spectrophotometer (Perkin Elmer 3300), with five repetitions for each sample. The mean and standard deviation were determined. Different biological factors as indicators of the ability of the plant species of bioaccumulation, translocation and phytoremediation of researched metals were calculated as presented in the next table (Table 1 ).

Table 1. Formulas for calculating the factors for bioaccumulation, translocation, enrichment and absorption coefficient

\begin{tabular}{|c|c|c|}
\hline Factor & Formulas & Elements of formula \\
\hline $\begin{array}{l}\text { Bioaccumulation factor }(\mathrm{BF}) \\
\text { (Ghosh and Sing, 2005) }\end{array}$ & $\mathrm{BF}=\mathrm{C}_{\text {root }} / \mathrm{C}_{\text {soil }}$ & \multirow{4}{*}{$\begin{array}{l}\mathrm{C}_{\text {root }} \text { - the metal concentration in the plant root } \\
\mathrm{C}_{\text {soil }} \text { - the metal concentration in the soil } \\
\mathrm{C}_{\text {stem }} \text { - the metal concentration in the plant stem } \\
\mathrm{C}_{\text {leaf }} \text { - the metal concentration in the plant leaf } \\
\mathrm{C}_{\text {plant }} \text { - the metal concentration in the whole plant }\end{array}$} \\
\hline $\begin{array}{l}\text { Translocation factor }(\mathrm{TF}) \\
\text { (Gupta et al., 2008) }\end{array}$ & $\begin{aligned} \mathrm{TF}_{\text {stem }} & =\mathrm{C}_{\text {stem }} / \mathrm{C}_{\text {root }} \\
\mathrm{TF}_{\text {leaf }} & =\mathrm{C}_{\text {leaf }} / \mathrm{C}_{\text {root }}\end{aligned}$ & \\
\hline $\begin{array}{l}\text { Enrichment factor }(\mathrm{EF}) \\
\text { (Ghosh and Sing, 2005) }\end{array}$ & $\begin{aligned} \mathrm{EF}_{\text {stem }} & =\mathrm{C}_{\text {stem }} / \mathrm{C}_{\text {soil }} \\
\mathrm{EF}_{\text {leaf }} & =\mathrm{C}_{\text {leaf }} / \mathrm{C}_{\text {soil }}\end{aligned}$ & \\
\hline $\begin{array}{l}\text { Biological Absorption coefficient } \\
\text { (AC) (Kabata-Pendias, 2001) }\end{array}$ & $\mathrm{AC}=\mathrm{C}_{\text {plant }} / \mathrm{C}_{\text {soil }}$ & \\
\hline
\end{tabular}




\section{Statistical analysis}

The differences between groups were studied by the Multivariate Analysis of Variance (MANOVA). Using the two-factor analysis of the variance (2-way MANOVA), the degree of difference in the content of the investigated metals between groups was determined (species, organ and species $\times$ organ interaction). The Scheffe post-hoc test was used to determine the existence of statistical differences between pairs of groups (different organs of a single plant species). The main component analysis (PCA) was used to detect variables (analysed metals) that most contribute to the differences (separation) between the investigated groups (species and organs). Statistical analyses were carried out with the help of the program package Statistica 10.0 (StatSoft, 2011).

\section{Results and Discussion}

The emission of pollutants through various means of transport is an important anthropogenic source of metals, especially of those that are specifically related to traffic such as $\mathrm{Pb}, \mathrm{Cu}$ and $\mathrm{Zn}$ (Malinowska et al., 2015). This study showed that the mean values of the concentrations of the investigated elements in the soil were graded in the following order: $\mathrm{Ca}>\mathrm{Mg}>\mathrm{Fe}>\mathrm{Cr}>\mathrm{Mn}>\mathrm{Pb}>\mathrm{Zn}>\mathrm{Cu}$ and ranged from $30.86 \mathrm{mg} \mathrm{Cu} \mathrm{kg}^{-1}$ to 45,458.6 $\mathrm{mg} \mathrm{Ca} \mathrm{kg}^{-1}$ (Table 2).

Table 2 . The mean concentration of investigated metals $\left(\mathrm{mg} \mathrm{kg}^{-1}\right)$ in soil (mean value \pm standard deviation)

\begin{tabular}{|l|c|}
\hline \multicolumn{1}{|c|}{ Metal } & Concentration \\
\hline $\mathrm{Ca}$ & $45,458.60 \pm 74.36$ \\
\hline $\mathrm{Mg}$ & $36,313.00 \pm 101.62$ \\
\hline $\mathrm{Fe}$ & $27,427.20 \pm 74.12$ \\
\hline $\mathrm{Mn}$ & $434.94 \pm 1.96$ \\
\hline $\mathrm{Cu}$ & $30.86 \pm 0.50$ \\
\hline $\mathrm{Zn}$ & $31.70 \pm 0.58$ \\
\hline $\mathrm{Pb}$ & $91.50 \pm 0.97$ \\
\hline $\mathrm{Cr} \quad(\mathrm{n}=5)$ & $744.18 \pm 11.47$ \\
\hline
\end{tabular}

The obtained results showed that the concentrations of $\mathrm{Pb}$ and $\mathrm{Cr}$ in the investigated soil exceeded the prescribed maximum permissible concentrations and limit values of these metals in the soil, and that the concentration of $\mathrm{Cr}$ was above its remediation value, as determined by the regulations of the Republic of Serbia (Službeni glasnik RS, br. 18/97 or 23/94; Službeni glasnik RS, br. 88/2010). Also, the concentrations of Pb, $\mathrm{Cu}$ and $\mathrm{Cr}$ in the studied soil were above the mean concentrations of these metals compared to the results of some authors (Kabata-Pendias and Mukherjee, 2007; Pavlović et al., 2016), while the concentration of Cr was far higher than the literature data for its concentrations in the soils of Europe (Gawlik and Bidoglio, 2006; EU Directive 86/278/EEC, 1986). Besides, the concentrations of $\mathrm{Cu}, \mathrm{Mn}, \mathrm{Cr}$ and $\mathrm{Pb}$ in the studied soil were higher than the normal and mean values of the concentrations for the mentioned metals in relation to results of some other research (Gonzalez and Gonzales-Chavez, 2006; Aslam et al., 2013; Malinowska et al., 2015; Dikwa et al., 2019).

The results of the study showed that the content of tested metals in the investigated plant species varied in both, the plant's organ and the type of metal (Table 3). The leaves of species M. inodora contained almost all investigated metals (except $\mathrm{Pb}$ that was detected only in the root), but in higher concentrations than in root and stem. The leaves of $A$. millefolium species contained almost all of the investigated metals, also in higher concentrations than in the root and stem, while the root contained more $\mathrm{Cr}$ and $\mathrm{Pb}$ than other investigated organs. Concerning the species C. setosa, the highest content of $\mathrm{Ca}$ and $\mathrm{Cu}$ was found in the leaves, while the 
root of this species accumulated the highest amount of $\mathrm{Mg}, \mathrm{Fe}, \mathrm{Mn}, \mathrm{Zn}, \mathrm{Pb}$ and $\mathrm{Cr}$ compared to other investigated organs.

Table 3. The mean concentration of the metals $\left(\mathrm{mg} \mathrm{kg}^{-1}\right)$ in the investigated species (mean value \pm standard deviation)

\begin{tabular}{|c|c|c|c|c|}
\hline \multicolumn{5}{|c|}{ M. inodora } \\
\hline & Root & Stem & Leaf & Whole plant \\
\hline $\mathrm{Ca}$ & $14,573.40 \pm 210.38$ & $14,324.80 \pm 36.95$ & $22,618.60 \pm 240.35$ & $17,172.27 \pm 3991.39$ \\
\hline $\mathrm{Mg}$ & $2,797.00 \pm 77.74$ & $2,364.00 \pm 41.02$ & $4,647.40 \pm 36.18$ & $3,269.47 \pm 1026.27$ \\
\hline $\mathrm{Fe}$ & $1,062.20 \pm 37.90$ & $667.30 \pm 18.65$ & $1,638.60 \pm 30.09$ & $1,122.70 \pm 413.76$ \\
\hline $\mathrm{Mn}$ & $29.59 \pm 0.34$ & $21.62 \pm 1.08$ & $61.16 \pm 0.46$ & $37.46 \pm 17.69$ \\
\hline $\mathrm{Cu}$ & $11.24 \pm 0.55$ & $6.17 \pm 0.14$ & $14.02 \pm 0.49$ & $10.48 \pm 3.39$ \\
\hline $\mathrm{Zn}$ & $47.59 \pm 0.32$ & $43.72 \pm 0.69$ & $65.76 \pm 0.66$ & $52.36 \pm 9.96$ \\
\hline $\mathrm{Pb}$ & $5.51 \pm 0.29$ & $0 \pm 0$ & $0 \pm 0$ & $1.84 \pm 2.69$ \\
\hline $\mathrm{Cr}$ & $18.94 \pm 0.89$ & $19.30 \pm 0.36$ & $95.36 \pm 2.66$ & $44.53 \pm 37.23$ \\
\hline \multicolumn{5}{|c|}{ A. millefolium } \\
\hline & Root & Stem & Leaf & Whole plant \\
\hline $\mathrm{Ca}$ & $1,3041.22 \pm 48.84$ & $8,370.42 \pm 24.88$ & $19,441.60 \pm 327.63$ & $13,617.75 \pm 4700.77$ \\
\hline $\mathrm{Mg}$ & $2,868.58 \pm 37.20$ & $1,256.94 \pm 21.12$ & $3,059.80 \pm 40.43$ & $2,395.11 \pm 837.55$ \\
\hline $\mathrm{Fe}$ & $1,261.80 \pm 11.35$ & $428.66 \pm 2.42$ & $1,693.60 \pm 14.71$ & $1,128.02 \pm 543.52$ \\
\hline $\mathrm{Mn}$ & $38.59 \pm 0.33$ & $9.57 \pm 0.23$ & $48.98 \pm 0.32$ & $32.38 \pm 17.27$ \\
\hline $\mathrm{Cu}$ & $7.75 \pm 0.21$ & $2.32 \pm 0.02$ & $9.75 \pm 0.11$ & $6.60 \pm 3.25$ \\
\hline $\mathrm{Zn}$ & $33.51 \pm 0.37$ & $23.22 \pm 0.61$ & $34.74 \pm 0.47$ & $30.49 \pm 5.37$ \\
\hline $\mathrm{Pb}$ & $12.59 \pm 0.26$ & $1.04 \pm 0.02$ & $3.14 \pm 0.11$ & $5.59 \pm 5.20$ \\
\hline $\mathrm{Cr}$ & $36.34 \pm 0.48$ & $14.00 \pm 0.15$ & $36.09 \pm 0.34$ & $28.81 \pm 10.84$ \\
\hline \multicolumn{5}{|c|}{ C. setosa } \\
\hline & Root & Stem & Leaf & Whole plant \\
\hline $\mathrm{Ca}$ & $15,406.80 \pm 50.88$ & $14,310.60 \pm 47.86$ & $17,785.00 \pm 83.82$ & $15,834.13 \pm 1502.28$ \\
\hline $\mathrm{Mg}$ & $6,356.20 \pm 483.42$ & $3,263.20 \pm 38.15$ & $6,290.20 \pm 91.53$ & $5,303.20 \pm 1516.50$ \\
\hline $\mathrm{Fe}$ & $1,751.60 \pm 37.00$ & $853.42 \pm 30.26$ & $543.26 \pm 11.30$ & $1,049.43 \pm 531.04$ \\
\hline $\mathrm{Mn}$ & $54.44 \pm 0.75$ & $10.42 \pm 0.47$ & $43.64 \pm 0.62$ & $36.17 \pm 19.40$ \\
\hline $\mathrm{Cu}$ & $13.62 \pm 0.40$ & $8.49 \pm 0.28$ & $18.66 \pm 0.48$ & $13.59 \pm 4.31$ \\
\hline $\mathrm{Zn}$ & $76.82 \pm 0.83$ & $41.90 \pm 0.78$ & $57.52 \pm 1.50$ & $58.75 \pm 14.82$ \\
\hline $\mathrm{Pb}$ & $12.28 \pm 0.52$ & $2.24 \pm 0.07$ & $7.42 \pm 0.27$ & $7.31 \pm 4.25$ \\
\hline $\mathrm{Cr}$ & $66.06 \pm 0.50$ & $18.62 \pm 0.45$ & $50.72 \pm 0.49$ & $45.13 \pm 20.46$ \\
\hline
\end{tabular}

\section{Calcium and magnesium}

The results obtained for the whole plant material showed: the concentrations of Ca in plant were graded in the following order: $M$. inodora $>$ C. setosa $>$ A. millefolium, while the order for the content of Mg was: $C$. setosa $>$ M. inodora $>$ A. millefolium. The highest content of $\mathrm{Ca}\left(8,370.42 \mathrm{mg} \mathrm{kg}^{-1}\right)$ was recorded in the stem of $A$. milllefolium, and the smallest in the leaf of $M$. inodora species $\left(22,618.6 \mathrm{mg} \mathrm{kg}^{-1}\right)$. The stem of $A$. millefolium contained a maximum of $\mathrm{Mg}\left(1,256.94 \mathrm{mg} \mathrm{kg}^{-1}\right)$, while the smallest content of this metal was recorded in the root of $C$. setosa $\left(6,356.2 \mathrm{mg} \mathrm{kg}^{-1}\right)$.

\section{Iron}

Starting from the highest content, the order of determined Fe concentrations in whole plants of the studied species was: A. millefolium > M. inodora > C. setosa. The lowest Fe concentration ( $\left.428.66 \mathrm{mg} \mathrm{kg}^{-1}\right)$ was recorded in the stem of species $A$. millefolium, while its concentration was the highest in the root of $C$. setosa $\left(1,751.6 \mathrm{mg} \mathrm{kg}^{-1}\right)$. Fe is an essential element for plants and is necessary in numerous biological processes 
(photosynthesis, chloroplast formation, chlorophyll biosynthesis, redox system). Plants uptake Fe in the form of ions $\left(\mathrm{Fe}^{2+}, \mathrm{Fe}^{3+}\right)$ and it chelate compounds. The literature data state normal Fe concentrations $(8-100 \mathrm{mg} \mathrm{kg}$ 1) (Nagajyoti et al., 2010), as well as various toxic values of this metal for plants ( $40-500 \mathrm{mg} \mathrm{Fe} \mathrm{kg}{ }^{-1}, 5-200 \mathrm{mg}$ $\mathrm{Fe} \mathrm{kg}^{-1}$ ) (Allen, 1989; Markert, 1992). According to Hooda (2010), the Fe concentration in plant tissues comes up to $50 \mathrm{mg} \mathrm{kg}^{-1}$, while the excessive values are in the range of $50-500 \mathrm{mg} \mathrm{kg}^{-1}$. All of the investigated species contained above toxic levels of iron in their organs (except stem of species $A$. millefolium).

\section{Manganese}

$\mathrm{Mn}$ is actively adopted and quickly transported through plants (in the form of $\mathrm{Mn}^{+2}$ ), so it is mostly accumulated in young organs (stem, root) and xylem juice. The content of $\mathrm{Mn}$ in all the studied plants decreased in the following order: M. inodora $>A$. millefolium $>C$. setosa. The highest content of Mn was recorded in the leaf of $M$. inodora species $\left(61.15 \mathrm{mg} \mathrm{kg}^{-1}\right)$, and the smallest in the stem of $A$. millefolium $(9.57$ $\left.\mathrm{mg} \mathrm{kg}^{-1}\right)$. According to some authors, for most plants, the normal content of $\mathrm{Mn}$ is in the range of $20-300 \mathrm{mg}$ $\mathrm{kg}^{-1}$ (Pais and Jones, 2000), while the $\mathrm{Mn}$ values of 30-300 mg kg${ }^{-1}$ in a tissue are considered to be excessive (Kabata-Pendias, 2011). There are some other findings that suggest the normal Mn concentration of 15-100 $\mathrm{mg} \mathrm{kg}^{-1}$ (Nagajyoti et al., 2010) and 2-100 $\mathrm{mg} \mathrm{kg}^{-1}$ (Alloway, 1990), while the toxicity threshold is 170-2,000 $\mathrm{mg} \mathrm{kg}^{-1}$ (Vamerali et al., 2010) and 300-500 $\mathrm{mg} \mathrm{kg}^{-1}$ (Alloway, 1990). The results obtained in our study showed increased $\mathrm{Mn}$ content in the roots and leaves of the studied plants.

\section{Copper}

The highest content of $\mathrm{Cu}$ was determined in the species C. setosa (leaf $-18.66 \mathrm{mg} \mathrm{kg}^{-1}$ ) and the smallest in the species $A$. millefolium (stem $-2.32 \mathrm{mg} \mathrm{kg}^{-1}$ ). Plant uptake the $\mathrm{Cu}$ actively and/or passively in the form of $\mathrm{Cu}^{+2}$ ion and chelates through the roots, as well as by above-ground organs. $\mathrm{Cu}$ is the most movable element in plants and its translocation through the plant does not coincide with the intensity of the root system uptake. According to Hooda (2010), the normal concentration of $\mathrm{Cu}$ in plant tissues is in the range of $2-5 \mathrm{mg} \mathrm{kg}^{-1}$, while the excessive concentrations are $5-30 \mathrm{mg} \mathrm{kg}^{-1}$. In contrast to this opinion, however, some literature data indicate that the normal concentrations of this metal in leaf tissue are $5-30 \mathrm{mg} \mathrm{kg}^{-1}$ (Kabata-Pendias, 2011). All three investigated species of Asteraceae family had normal concentrations, compared to the abovementioned literature data.

\section{Zinc}

Based on the determined content of $\mathrm{Zn}$ in the whole plant material, species could be lined as follows: $C$. setosa $>$ M. inodora $>A$. millefolium. The highest content of $\mathrm{Zn}$ was found in the root of the $C$. setosa species ( $\left.76.82 \mathrm{mg} \mathrm{kg}^{-1}\right)$, while the stem of the $A$. millefolium contained the smallest amount of this metal $(23.22 \mathrm{mg}$ $\left.\mathrm{kg}^{-1}\right)$. $\mathrm{n}$ is an essential element that is characterized by high biological accessibility for plants and is mainly accumulated in roots and leaves of plants. According to Brunetti (2009), the normal content of $\mathrm{Zn}$ in plants is $15-150 \mathrm{mg} \mathrm{kg}^{-1}$, while the maximum value of $\mathrm{Zn}$ in plant tissues is $150-200 \mathrm{mg} \mathrm{kg}^{-1}$. For Hooda (2010), $\mathrm{Zn}$ concentration in plant tissues ranges from $10-20 \mathrm{mg} \mathrm{kg}^{-1}$, while its excessive values are $20-150 \mathrm{mg} \mathrm{kg}^{-1}$. Some other authors reported that the normal concentrations of $\mathrm{Zn}$ are $15-20 \mathrm{mg} \mathrm{kg}^{-1}$ (Marschner, 1995), while the toxicity threshold for $\mathrm{Zn}$ is $150-200 \mathrm{mg} \mathrm{kg}^{-1}$ (Brunetti et al., 2009), and 100-400 $\mathrm{mg} \mathrm{kg}^{-1}$ (Alloway, 1990), respectively. The $\mathrm{Zn}$ concentrations in the organs of plant species studied were in the normal range according to the literature data.

\section{Lead}

The highest content of $\mathrm{Pb}$ was found in the root of species A. millefolium $\left(12.59 \mathrm{mg} \mathrm{kg}^{-1}\right)$ and the lowest in the stem of the same species $\left(1.04 \mathrm{mg} \mathrm{kg}^{-1}\right)$. No presence of $\mathrm{Pb}$ was detected in the stem and in the leaf of species $M$. inodora, which indicates its poor mobility and that it is mainly being deposited in the root of plants. $\mathrm{Pb}$ is a nonessential element for plants that have limited accessibility from the soil solution. Plant roots 
accumulate $\mathrm{Pb}$ in large quantities due to its passive intake. $\mathrm{Pb}$ in the soil occurs in several oxidation forms and is poorly accessible to plants in its inorganic form, while it strongly binds to organic matter. The main source of $\mathrm{Pb}$ in the soil is the atmospheric deposition and its accumulation in organic and surface organic-mineral layers. According to some authors, the content of $\mathrm{Pb}$ in plants ranges from $0.05-3.0 \mathrm{mg} \mathrm{kg}^{-1}$ (Kabata-Pendias, 2011), but for others, the normal $\mathrm{Pb}$ concentration is $1-13 \mathrm{mg} \mathrm{kg}^{-1}$ (Nagajyoti et al., 2010) and $0.2-20 \mathrm{mg} \mathrm{kg}^{-1}$ (Alloway, 1990), respectively, whereas the toxicity threshold for $\mathrm{Pb}$ is $10-200 \mathrm{mg} \mathrm{kg}^{-1}$ (Vamerali et al., 2010). Increased $\mathrm{Pb}$ content in the roots can be attributed to its high content in the studied soil, while its high content in the leaves of the studied plants can be explained by a great influence of frequent traffic and the presence of this metal in the exhaust gases.

\section{Chrome}

The content of $\mathrm{Cr}$ in whole plants had the following declining order: $M$. inodora $>C$. setosa $>A$. millefolium. The highest concentration of this metal was recorded in the leaves of $M$. inodora $\left(95.36 \mathrm{mg} \mathrm{kg}^{-1}\right)$, and the lowest in the stem of $A$. millefolium $\left(14 \mathrm{mg} \mathrm{kg}^{-1}\right)$. Cr is toxic for agronomic plants at about $0.5-5.0 \mathrm{mg}$ $\mathrm{kg}^{-1}$ in nutrient solution and 5-100 $\mathrm{mg} \mathrm{kg}^{-1}$ in a soil (Oliveira, 2012). Under normal conditions, concentration of $\mathrm{Cr}$ in plants is less than $1 \mathrm{mg} \mathrm{kg}^{-1}$ (Mortvedt and Giordano, 1975). According to some authors, the critical concentration of $\mathrm{Cr}$ in plant tissues is $1-2 \mathrm{mg} \mathrm{kg}^{-1}$, the excessive values of this metal in leaves range from 0.1-0.5 $\mathrm{mg} \mathrm{kg}^{-1}$, while concentrations of $5-30 \mathrm{mg} \mathrm{kg}^{-1}$ are considered to be toxic for the leaf tissue (Kabata-Pendias, 2011). For some other authors, the normal concentration of Cr is $0.2-1 \mathrm{mg} \mathrm{kg}^{-1}$ (Nagajyoti et al., 2010), and $0.03-14 \mathrm{mg} \mathrm{kg}^{-1}$ (Alloway, 1990) respectively, while the toxicity threshold for Cr is $1-2 \mathrm{mg} \mathrm{kg}^{-1}$ (Vamerali et al., 2010), and 5-30 $\mathrm{mg} \mathrm{kg}^{-1}$ (Alloway, 1990), respectively. The Cr concentrations in the studied plant species exceeded many times over the critical and excessive concentrations of this metal in plants, as well as its toxic values in leaves compared to the above cited literature sources.

The obtained results showed that the studied species have different capacity for accumulation of the tested metals. The comparison of accumulation of the investigated metals by the species tested revealed that $M$. inodora had the better accumulation of $\mathrm{Ca}, \mathrm{Mn}$ and $\mathrm{Cr}$, C. setosa of $\mathrm{Mg}, \mathrm{Cu}, \mathrm{Zn}$ and $\mathrm{Pb}$, and A. millefolium of $\mathrm{Fe}$. In all studied species, the content of $\mathrm{Fe}$ and $\mathrm{Cr}$ was above toxic values.

Plant species that have a great ability to accumulate and translocate metal from their root to aboveground organs can be useful in removing metal from the soil and applied in the phytoremediation of contaminated soils (Porebska and Ostrowska, 1999). Using the bioaccumulation factor, plant's ability to accumulate metals from the soil can be estimated, while the ability of plants to translocate metals from the root to the above-ground organs can be determined by the translocation factor. According to some authors, TF > 1 shows the great ability of plants to transport nutrients from the root to the above-ground organs, most likely due to efficient metal transport systems (Zhao et al., 2007). According to Fitz and Wenzel (2002) plants that exhibit TF, and especially BF values greater than one are suitable for the phytoextraction. The enrichment factor estimates the translocation of metals from the soil to the above-ground organs. According to KabataPendias and Dudka (1991), depending on the EF values, the accumulation efficiency can be: intensive, EF >1; medium, $\mathrm{EF}=1-0.1$; weak, $\mathrm{EF}=0.1-0.01$; and no accumulation, $\mathrm{EF}=0.01-0.001$. Plants whose shoots (stem and leaf) have the EF $>1$ are considered as species with phytoextraction potential (Zacchini et al., 2009). All three biological factors can be applied in the estimation of plant specie's potential for its application in phytoremediation. The biological absorption coefficient of the metal is used to determine the amount of metal adopted by plants from the soil (Kabata-Pendias, 2011). The value of this coefficient for certain plant species greater than one indicates the possibility of their application in the phytoremediation. The value greater than two is considered significantly high (Pandy and Tripathi, 2010).

In the investigated organs of the $M$. inodora species, the content of almost all investigated metals was lower compared to that in the soil (except $\mathrm{Zn}$ content) (Table 4). The stem of this species contained more $\mathrm{Cr}$ than the root. The leaves of $M$. inodora species have accumulated more $\mathrm{Ca}, \mathrm{Mg}, \mathrm{Fe}, \mathrm{Mn}, \mathrm{Cu}, \mathrm{Zn}$ and $\mathrm{Cr}$ than 
the root and stem. So, it was found that the contents of $\mathrm{Ca}, \mathrm{Mg}, \mathrm{Fe}, \mathrm{Mn}, \mathrm{Cu}, \mathrm{Zn}$ and $\mathrm{Cr}$ were higher in the above-ground than in the underground parts of this plant.

The $M$. inodora species showed an intensive accumulation of $\mathrm{Zn}$, a medium accumulation of $\mathrm{Ca}$ and $\mathrm{Cu}$ in the stem and leaves, and a medium accumulation of $\mathrm{Cr}$ in the leaves. The obtained results indicate that only a minor part of $\mathrm{Pb}$ was adopted and accumulated in the root, while it was absent in the stem and leaves. The root of this species retains only a part of the $\mathrm{Zn}$, and the rest is translocated and accumulated in the leaves. Despite its large content in the soil, $\mathrm{Cr}$ is adopted in a small percentage by the roots of this species, so that its large content in the leaves (fivefold higher content than in the root and stem) can be attributed to good leaf absorption.

Table 4. The biological factors (Bioaccumulation, Translocation and Enrichment) and biological absorption coefficients of the investigated species

\begin{tabular}{|c|c|c|c|c|c|c|c|c|}
\hline \multicolumn{9}{|c|}{ M. inodora } \\
\hline & $B F$ & EFstem & EFleaf & $A F$ & TFstem & TFleaf & leaf/stem & above/under \\
\hline $\mathrm{Ca}$ & 0.32 & 0.32 & 0.50 & 0.38 & 0.98 & 1.55 & 1.58 & 2.53 \\
\hline $\mathrm{Mg}$ & 0.08 & 0.07 & 0.13 & 0.09 & 0.85 & 1.66 & 1.97 & 2.51 \\
\hline $\mathrm{Fe}$ & 0.04 & 0.02 & 0.06 & 0.04 & 0.63 & 1.54 & 2.46 & 2.17 \\
\hline $\mathrm{Mn}$ & 0.07 & 0.05 & 0.14 & 0.09 & 0.73 & 2.07 & 2.83 & 2.80 \\
\hline $\mathrm{Cu}$ & 0.36 & 0.20 & 0.45 & 0.34 & 0.55 & 1.25 & 2.27 & 1.80 \\
\hline $\mathrm{Zn}$ & 1.50 & 1.38 & 2.07 & 1.65 & 0.92 & 1.38 & 1.50 & 2.30 \\
\hline $\mathrm{Pb}$ & 0.06 & 0 & 0 & 0.02 & 0 & 0 & 0 & 0 \\
\hline $\mathrm{Cr}$ & 0.03 & 0.03 & 0.13 & 0.06 & 1.02 & 5.03 & 4.94 & 6.05 \\
\hline \multicolumn{9}{|c|}{ A. millefolium } \\
\hline & $\mathrm{BF}$ & EFstem & EFleaf & $\mathrm{AF}$ & TFstem & TFleaf & leaf/stem & above/under \\
\hline $\mathrm{Ca}$ & 0.29 & 0.18 & 0.43 & 0.30 & 0.64 & 1.49 & 2.32 & 2.13 \\
\hline $\mathrm{Mg}$ & 0.08 & 0.03 & 0.08 & 0.07 & 0.44 & 1.07 & 2.43 & 1.50 \\
\hline $\mathrm{Fe}$ & 0.05 & 0.02 & 0.06 & 0.04 & 0.34 & 1.34 & 3.95 & 1.68 \\
\hline $\mathrm{Mn}$ & 0.09 & 0.02 & 0.11 & 0.07 & 0.25 & 1.27 & 5.12 & 1.52 \\
\hline $\mathrm{Cu}$ & 0.25 & 0.08 & 0.32 & 0.21 & 0.30 & 1.26 & 4.21 & 1.56 \\
\hline $\mathrm{Zn}$ & 1.06 & 0.73 & 1.10 & 0.96 & 0.69 & 1.04 & 1.50 & 1.73 \\
\hline $\mathrm{Pb}$ & 0.14 & 0.01 & 0.03 & 0.06 & 0.08 & 0.25 & 3.02 & 0.33 \\
\hline $\mathrm{Cr}$ & 0.05 & 0.02 & 0.05 & 0.04 & 0.39 & 1.00 & 2.58 & 1.38 \\
\hline \multicolumn{9}{|c|}{ C. setosa } \\
\hline & $\mathrm{BF}$ & EFstem & EFleaf & $\mathrm{AF}$ & TFstem & TFleaf & leaf/stem & above/under \\
\hline $\mathrm{Ca}$ & 0.34 & 0.31 & 0.39 & 0.36 & 0.93 & 1.15 & 1.24 & 2.08 \\
\hline $\mathrm{Mg}$ & 0.18 & 0.09 & 0.17 & 0.14 & 0.51 & 1.00 & 1.93 & 1.50 \\
\hline $\mathrm{Fe}$ & 0.06 & 0.03 & 0.02 & 0.04 & 0.49 & 0.31 & 0.64 & 0.80 \\
\hline $\mathrm{Mn}$ & 0.13 & 0.02 & 0.10 & 0.08 & 0.19 & 0.80 & 4.19 & 1.00 \\
\hline $\mathrm{Cu}$ & 0.44 & 0.28 & 0.60 & 0.45 & 0.62 & 1.37 & 2.20 & 2.00 \\
\hline $\mathrm{Zn}$ & 2.42 & 1.32 & 1.81 & 1.83 & 0.55 & 0.75 & 1.37 & 1.29 \\
\hline $\mathrm{Pb}$ & 0.13 & 0.02 & 0.08 & 0.07 & 0.18 & 0.60 & 3.31 & 0.79 \\
\hline $\mathrm{Cr}$ & 0.09 & 0.03 & 0.07 & 0.06 & 0.28 & 0.77 & 2.72 & 1.05 \\
\hline
\end{tabular}

The obtained results also showed that the content of $\mathrm{Zn}$ in the root and the leaf of the species $A$. millefolium was higher than its content in the studied soil. The leaves of this species contained more $\mathrm{Ca}, \mathrm{Mg}$, $\mathrm{Fe}, \mathrm{Mn}, \mathrm{Cu}, \mathrm{Zn}$ and $\mathrm{Cr}$ than the root and stem. The same applies to the above-ground parts in relation to the underground parts of this plant. Also, the leaves of $A$. millefolium species accumulated more $\mathrm{Pb}$ than the stem. The species $A$. millefolium showed intensive accumulation of $\mathrm{Zn}$ in the leaves, as well as a medium accumulation of $\mathrm{Ca}$ in stem and leaves, $\mathrm{Cu}$ and $\mathrm{Mn}$ in the leaves and $\mathrm{Zn}$ in the stem. Based on these results, it can be assumed that a part of the entered $\mathrm{Zn}$ accumulates into the root and then is translocated into the leaf, 
while $\mathrm{Ca}, \mathrm{Mg}, \mathrm{Fe}, \mathrm{Mn}, \mathrm{Cu}$, and a part $\mathrm{Cr}$ are accumulated in the leaves of this species. The content of $\mathrm{Pb}$ in the leaves was fourfold smaller than in the root, and threefold higher than in the stem, so it can be concluded that a part of the accumulated $\mathrm{Pb}$ originates from its absorption from the air.

The contents of almost all investigated metals (except $\mathrm{Zn}$ ) in the tissues of the root, stem and leaf, and in the material prepared from the entire body of the plant C. setosa were smaller than their content in the soil. The leaves of the $C$. setosa species contained more $\mathrm{Ca}, \mathrm{Mg}$ and $\mathrm{Cu}$ than its root. Also, the contents of almost all investigated metals (except $\mathrm{Fe}$ ) were higher in the leaves than in the stem of this species. The results showed that the above-ground parts accumulated less $\mathrm{Fe}$ and $\mathrm{Pb}$ than the underground parts of this plant. The species C. setosa showed intensive accumulation of $\mathrm{Ca}$ and $\mathrm{Cu}$ in the leaves, as well as a medium accumulation of all other test metals in the stem and leaves. One part of the absorbed quantities of studied metals this plant species translocated through the root and stem, and metals like $\mathrm{Ca}, \mathrm{Mg}$ and $\mathrm{Cu}$ accumulated in its leaves. The obtained results indicate that $\mathrm{Zn}$ is mostly retained in the root, and then translocated and accumulated in the leaves of this species. Also, given the low absorption capacity of $\mathrm{Pb}$ and its small translocation, it can be assumed that the primary origin of this metal in the leaves is atmospheric.

The results of this study have shown that all three studied species (especially $C$. setosa) have the ability to accumulate $\mathrm{Zn}$ in their roots. Also, the species $M$. inodora and $C$. setosa had the AF $>1$ for $\mathrm{Zn}$, which places them in the category of plants that can be applied in the phytoremediation of soils loaded with this metal.

Based on the results for the translocation factor, there is a potential for application of leaves of the $M$. inodora and $A$. millefolium species in the phytoextraction of $\mathrm{Ca}, \mathrm{Mg}, \mathrm{Fe}, \mathrm{Mn}, \mathrm{Cu}, \mathrm{Zn}$ and $\mathrm{Cr}$, and leaves of the $C$. setosa species in the phytoextraction of $\mathrm{Ca}, \mathrm{Mg}$ and $\mathrm{Cu}$, and the stem of $M$. inodora species in the phytoextraction of Cr. The results of this study showed the species M. inodora and C. setosa have the ability to absorb $\mathrm{Zn}$ from the soil and translocate it to the stem and leaves, while the species $A$. millefolium adopts $\mathrm{Zn}$ from the root and transports it directly to the leaves and accumulates it there. Also, the species C. setosashowed an intensive accumulation of $\mathrm{Ca}$ and $\mathrm{Cu}$ in the leaves and a medium accumulation of all other test metals in the stem and leaves. The species $A$. millefolium showed an intensive accumulation of $\mathrm{Zn}$ in the leaves and a medium accumulation of $\mathrm{Ca}$ the in stem and leaves, $\mathrm{Cu}$ and $\mathrm{Mn}$ in the leaves and $\mathrm{Zn}$ in the stem, while the species $M$. inodora showed intensive accumulation of $\mathrm{Zn}$ and a medium accumulation of $\mathrm{Ca}$ and $\mathrm{Cu}$ in the stem and leaves and also a medium accumulation of $\mathrm{Cr}$ in the leaves.

The multivariate analysis of variance (MANOVA) has shown that there are statistically significant differences between the investigated groups (plant species and organs) regarding the content of all investigated metals ( $\mathrm{p}<0.001)$. The Scheffe Test (Sheffe's Post-Hoc test) showed that there are statistically significant differences between almost all pairs of groups (different plant organs of one species) in terms of the content of investigated metals $(\mathrm{p}<0.001)$. It was found that there are no significant differences in the following pairs of groups: stem and leaf, as well as the root and stem of the $M$. inodora species for Ca; the root and stem of $M$. inodora, as well as the root and the leaf of C. setosa for Mg; the root and leaf of the A. millefolium, as well as between these organs and the examined soil for $\mathrm{Zn}$; the stem and leaf of $M$. inodora for $\mathrm{Pb}$; and the root and leaf of $A$. millefolium species for $\mathrm{Cr}$.

The results of the two-factor multivariate analysis of variance (2-way MANOVA) showed that the main effects of the organ $(F=4,470.16)$, then the species $(F=1,572.49)$ and the interaction organ*species $(F=$ $867.73)$ on the content of studied metals are statistically significant $(\mathrm{p}<0.001)$. The organs of the studied plant species had the highest degree of influence on the content of the investigated metals. The results of a two-factor univariate analysis of variance (2-way ANOVA) indicate that the statistically significant effects of the investigated groups (species, organ, and species*organ) were detected in all studied metals $(\mathrm{p}<0.001)$ (Table 5). The content of $\mathrm{Ca}, \mathrm{Fe}, \mathrm{Mn}, \mathrm{Cu}, \mathrm{Pb}$ and $\mathrm{Cr}$ was mostly dependent on the type of plants' organs, while the content of $\mathrm{Mg}$ and $\mathrm{Zn}$ was mostly determined by the plant species. 
Table 5. Effects of organ, species, and organ*species on chemical elements concentrations

\begin{tabular}{|l|c|c|c|c|c|c|}
\hline & \multicolumn{2}{|c|}{ Organ } & \multicolumn{2}{c|}{ Species } & \multicolumn{2}{c|}{ Organ*Species } \\
\cline { 2 - 7 } & $\mathrm{F}$ & $\mathrm{p}$ & $\mathrm{F}$ & $\mathrm{p}$ & $\mathrm{F}$ & $\mathrm{p}$ \\
\hline $\mathrm{Ca}$ & 9316.3 & ${ }^{* * *}$ & 1928.2 & ${ }^{* * *}$ & 956.7 & ${ }^{* * *}$ \\
\hline $\mathrm{Mg}$ & 789.93 & ${ }^{* * *}$ & 1173.89 & ${ }^{* * *}$ & 94.88 & ${ }^{* * *}$ \\
\hline $\mathrm{Fe}$ & 3791.58 & ${ }^{* * *}$ & 47.75 & ${ }^{* * *}$ & 2419.44 & ${ }^{* * *}$ \\
\hline $\mathrm{Mn}$ & 17159.3 & ${ }^{* * *}$ & 320.7 & ${ }^{* * *}$ & 2021.0 & ${ }^{* * *}$ \\
\hline $\mathrm{Cu}$ & 2269.98 & ${ }^{* * *}$ & 1518.37 & ${ }^{* * *}$ & 32.48 & ${ }^{* * *}$ \\
\hline $\mathrm{Zn}$ & 2275.8 & ${ }^{* * *}$ & 5588.6 & ${ }^{* * *}$ & 917.3 & ${ }^{* * *}$ \\
\hline $\mathrm{Pb}$ & 5767.91 & ${ }^{* * *}$ & 2069.52 & ${ }^{* * *}$ & 335.02 & ${ }^{* * *}$ \\
\hline $\mathrm{Cr}$ & 7026.77 & ${ }^{* * *}$ & 1275.82 & ${ }^{* * *}$ & 3157.75 & ${ }^{* * *}$ \\
\hline
\end{tabular}

The results of the analysis of the main components (PCA), based on the content of the investigated metals at the root, the stem and the leaf of studied species, indicated a clear separation of the plants' organs in terms of the metal content, and the greatest influence on these differences had $\mathrm{Mn}, \mathrm{Cr}, \mathrm{Mg}$ and $\mathrm{Zn}$ (Figure 2). Based on the distribution of the analysed organs (roots, stem and leaf) of the plants studied along the PC axes, a separation was noticed of the root and leaf of the $C$. setosa species regarding higher values for $\mathrm{Pb}$, while the leaf in the species $M$. inodora and $A$. millefolium had higher content values of other studied metals. The stem of all three species, as well as the root of $A$. millefolium and $M$. inodora, showed significantly lower content values of the investigated metals.

(A)

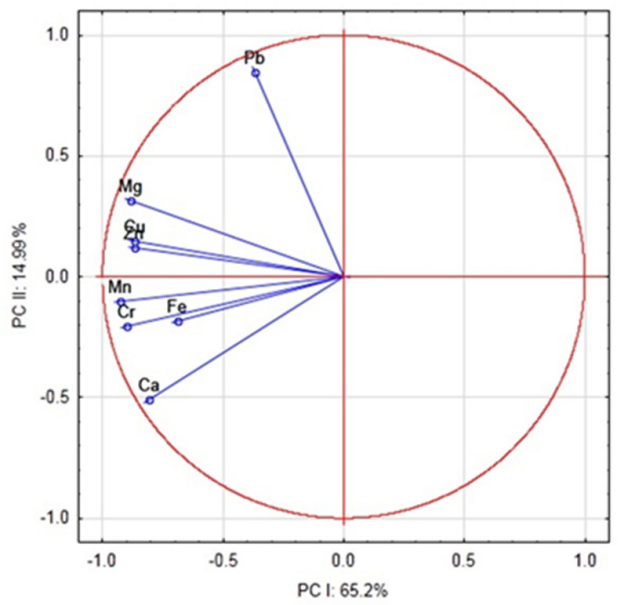

(B)

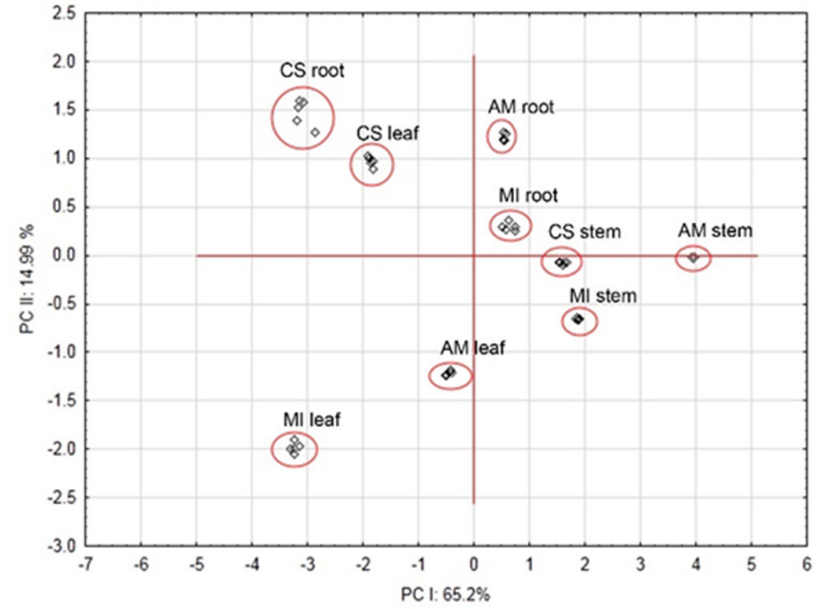

Figure 2. Principal component analysis (PCA): ordination of analysed chemical elements (A) and plant parts of investigated species (B) across discriminant axes (PC I and PC II) AM - A. millefolium, CS - C. setosa, MI - M. inodora.

Some studies have shown that the intensity of traffic and the behaviour of drivers in traffic affect the concentration of metals in soil and vegetation along the traffic routes (Malizia et al., 2012; Amusan et al., 2003). $\mathrm{Pb}$ from exhaust gases, $\mathrm{Cu}, \mathrm{Cr}, \mathrm{Cd}$ and $\mathrm{Zn}$ in motor oil additives, pneumatics, brake pads, corrosion protection agents, roadways, and various materials from the surface of pavement stripes are the main elements that pollute the environment around the roads (Denier van der Gon et al., 2007). Also, the atmosphere is a very important transport medium for metals from various sources. Metals are mainly present in the form of aerosols with a particle size of 5-20 mm in diameter and average retention in an atmosphere of 10-30 days (Kastori, 1997). Plant loading with heavy metals occurs when they are retained for a long time in the environment, resulting in their accumulation in the plant. 
The bioindicator is an organism (part of an organism or community of organisms) that contains information on an environmental quality (detect changes in the environment, indicate the presence of pollutants and their effects on the ecosystem) (Markert et al., 2003). The bioindicators point to the quality of changes in the environment, while the biomonitors are used to obtain quantitative information on the quality of biological monitoring of the environment. The application of higher plants for indication of soil contamination is based on their ability to "absorb" metals and other pollutants from the soil, transport them through their organism and accumulate. High correlation of metal content in soil and plants reflects the cumulative effects of environmental pollution that originate from the soil and indicates the potential application of plants in the biomonitoring of metals. According to some studies, the metal content in some plants increases with increase of their content in the environment (Bonanno, 2011), and plants with a metal content that are strongly in correlation with their content in the soil can be considered as potential indicators of metal availability (Alyemenia and Almohisen, 2014). Metal tolerant plants tend to limit their uptake from soil and their further transport from root to stem, reducing the accumulation of metals in plant biomass, while (hyper) accumulator species actively uptake and translocate metals into above-ground organs (Yoon et al., 2006). This study points out the potential for application of the studied species in bioindication and biomonitoring of the investigated metals.

The intensity of the uptake and accumulation of metals in plants depends on numerous factors. So, the uptake of metals by plants increases with decreasing soil $\mathrm{pH}$, increasing the content of organic matter and increasing available metal concentrations in the soil (Zeng et al., 2011). Metals, especially non-essential, are more intensively accumulated in the root than in the above-ground organs since it is the main route of metal entry into plants (Kumar et al., 2006). The ability and the potential of the roots to accumulate metals is one of the forms of the above-ground organs protection from their great concentration in the external environment. The intensity of the uptake and translocation of metals by xylem depends on the type of metal, plant species, but also on their participation in biochemical reactions during their uptake and transport, as well as the ability of metals to build chelate complexes with xylem components (Mullins et al., 1986; White, 2001). The accumulation is conditioned by the specific mechanism of plant tolerance towards the metal and/or its inclusion in certain physiological-biochemical processes.

The intensity of the absorption and transport of $\mathrm{Cu}$ in the above-ground organs is in a positive correlation with its concentration in the substrate. Also, the transport of $\mathrm{Cu}$ by xylem depends on its concentration in the soil solution, as well as on the amount of $\mathrm{Ca}$ and $\mathrm{Zn}$ ions present in it. $\mathrm{Zn}$ and $\mathrm{Cu}$ are primarily accumulated in the cell wall of the root and in the leaf cells, in vacuoles and mitochondria (He, 2006). Plants accumulate $\mathrm{Mn}$ in their physiologically less active parts (vacuoles of the trichomes cells of leaves, petioles, and parts of the roots). The inorganic form of $\mathrm{Pb}$ plants poorly uptake and translocate into the above-ground organs. The primary site of the $\mathrm{Pb}$ accumulation is the cell walls of the endoderm and the pericycle of the root. In contrast, $\mathrm{Pb}$ in organic form (alkali derivatives, tetra-alkyl-lead, tetramethyl lead, tetraethyl lead) is very mobile in soil and plants. Some studies show that some metals are mostly retained in underground organs (Weis and Weis, 2004; Bonanno, 2011), while the primary source of $\mathrm{Pb}$ for plants is its atmospheric deposition on leaves (Sawidis et al., 2011). Pb collecting in plants near the highways depends on several factors (the distance of plants from the roads, the land cover with the plant, the length of the vegetation, the direction and the intensity of the wind) (Jaradat and Momani, 1999; Birch and Scollen, 2003). The accumulation of metals in individual organs, tissues and various compartments of the plant's cell is characteristic of the plant species.

The results of this study showed that the type of organ of the studied plants have the greatest effect on the accumulation of the test metals. The accumulation of $\mathrm{Ca}, \mathrm{Fe}, \mathrm{Mn}, \mathrm{Cu}, \mathrm{Pb}$ and $\mathrm{Cr}$ depends on the type of organs, while the accumulation of $\mathrm{Mg}$ and $\mathrm{Zn}$ is affected by plant species. The species $M$. inodora and $A$. millefolium have similar ways of uptake, translocation and accumulation of the studied metals compared to the C. setosa species. 


\section{Conclusions}

The obtained results indicate metal contamination of the soil along the highway, especially with $\mathrm{Pb}$ and $\mathrm{Cr}$, whose concentrations in the investigated soil exceeded the prescribed maximum permissible concentrations and limit values. In addition, the concentration of $\mathrm{Cr}$ was above the remediation value as determined by the regulations of the Republic of Serbia. The results concerning to the phytoaccumulation of the metals have established that all three studied species have the ability to accumulate all of the investigated metals in their roots. This leads to the conclusion that they can be applied in phytostabilization, which is an effective method for reducing the pollutants' migration in soil. However, only the species M. inodora and C. setosa had the AF $>1$ for $\mathrm{Zn}$ and are therefore suitable for phytoremediation of that metal.

\section{Authors' Contributions}

Conceptualization: E, Investigation: AE, Methodology: BE, Writing - original draft: AE, Writing review and editing: AED, Statistic analysis: $C$.

All authors read and approved the final manuscript.

\section{Acknowledgements}

This research received no specific grant from any funding agency in the public, commercial, or not-forprofit sectors. The authors themselves funded this research.

Thanks are due to Vesna Jović-Glišić, holder of the Diploma of Professional Writing (Professional Editing and Proofreading) from Cengage Education, former Australian College of Journalism for professional editing and proofreading of the manuscript.

\section{Conflict of Interests}

The authors declare that there are no conflicts of interest related to this article.

\section{References}

Allen SE (1989). Chemical analysis of ecological materials. Blackwell Scientific Publications, London. Alloway BJ (1990). Heavy metals in soil. Blackie and Son Ltd, London.

Alyemenia MN, Almohisen IAA (2014). Traffic and industrial activities around Riyadh cause the accumulation of heavy metals in legumes: a case study. Saudi Journal of Biological Sciences 21:167-172. https://doi.org/10.1016/j.sjbs.2013.09.007

Amusan AA, Bada SB, Salami A (2003). Effect of traffic density on heavy metal content of soil and vegetation along roadside in Osun state, Nigeria. West African Journal of Applied Ecology 4:107-114.

Aslam J, Khan SA, Khan SH (2013). Heavy metals contamination in roadside soil near different traffic signals in Dubai, United Arab Emirates. Journal of Saudi Chemical Society 17(3):315-319. https://doi.org/10.1016/j.jscs.2011.04.015

Birch GF, Scollen A (2003). Heavy metals in road dust, gully pots and parkland soils in a highly urbanised sub-catchment of Port Jackson, Australia. Australian Journal of Soil Research 41:1329-1342. https://doi.org/10.1071/SR02147 
Bonanno G (2011). Trace element accumulation and distribution in the organs of Phragmites australis (common reed) and biomonitoring applications. Ecotoxicology and Environmental Safety 74:1057-1064. https://doi.org/10.1016/j.ecoenv.2011.01.018

Boonyapookana B, Parkpian P, Techapinyawat S, DeLaune RD, Jugsujinda A (2005). Phytoaccumulation of lead by sunflower (Helianthus annuus), tobacco (Nicotiana tabacum), and vetiver (Vetiveria zizanioides). Journal of Environmental Science and Health, Part A. Toxic/Hazardous Substances and Environmental Engineering 40(1):117-137. https://doi.org/10.1081/ESE-200033621

Branković S, Glišić R, Pavlović-Muratspahić D, Topuzović M, Đekić V (2013). Phytoaccumulation of some metals by three species of genus Alyssum on one serpentine locality (Serbia). Fresenius Environmental Bulletin 22(11):3146-3154. https://www.cabdirect.org/cabdirect/abstract/20143004983

Brunetti G, Soler-Rovira P, Farrag K, Senesi N (2009). Tolerance and accumulation of heavy metals by wild plant species grown in contaminated soils in Apulia region, Southern Italy. Plant and Soil 318:285-298. https://doi.org/10.1007/s11104-008-9838-3

Denier van der Gon HAC, Hulskotte JHJ, Visschedijk AJH, Schaap M (2007). A revised estimate of copper emissions from road transport in UNECE Europe and its impact on predicted copper concentrations. Atmospheric Environment 41:8697-8710. https://doi.org/10.1016/j.atmosenv.2007.07.033

Dikwa MK, Akan JC, Adamu A (2019). Determination of some heavy metals in roadside soils from some major roads in Maiduguri, Borno State, Nigeria. Nuclear Science 4(3):27-33. https://doi.org/10.11648/j.ns.20190403.11

Doğanlar ZB, Atmaca M (2011). Influence of airborne pollution on $\mathrm{Cd}, \mathrm{Zn}, \mathrm{Pb}, \mathrm{Cu}$, and $\mathrm{Al}$ accumulation and physiological parameters of plant leaves in Antakya (Turkey). Water, Air, \& Soil Pollution 214:509-523. https://doi.org/10.1007/s11270-010-0442-9

EU Directive $86 / 278 /$ EEC on the protection of the environment and in particular of the soil, when sewage sludge is used in agriculture (1986). The Official Journal of the European Union L181/6. https://www.legislation.gov.uk

Falahi-Ardakani A (1984). Contamination of environment with heavy metals emitted from automotive. Ecotoxicology and Environmental Safety 8(2):152-61. https://doi.org/10.1016/0147-6513(84)90057-5

Fitz WJ, Wenzel WW (2002). Arsenic transformation in the soil-rhizosphere-plant system, fundamentals and potential application of phytoremediation. Journal of Biotechnology 99:259-278. https://doi.org/10.1016/S01681656(02)00218-3

Gawlik BW, Bidoglio G (2006). Background values in European soils and sewage sludges. Part III, conclusion, comments and recommendations. European Commission, Directorate-General Joint Research Centre, Institute for Environment and Sustainability. https://www.isprambiente.gov.it

Ghosh M, Singh SP (2005). A comparative study of cadmium phytoextraction by accumulator and weeds species. Environmental pollution 133:365-371. https://doi.org/10.1016/j.envpol.2004.05.015

Gonzalez CR, Gonzales-Chavez MCA (2006). Metal accumulation in wild plants surrounding mining wastes. Environmental Pollution 144:84-92. https://doi.org/10.1016/j.envpol.2006.01.006

Gualtieri M, Andrioletti M, Mantecca P, Vismara C, Camatini M (2005). Impact of tire debris on in vitro and in vivo systems. Particle and Fibre Toxicology 2:1. https://doi.org/10.1186/1743-8977-2-1

Gupta S, Nayek S, Saha RN, Satpati S (2008). Assessment of heavy metal accumulation in macrophyte, agricultural soil and crop plants adjacent to discharge zone of sponge iron factory. Environmental Geology 55:731-739. https://doi.org/10.1007/s00254-007-1025-y

Hawkes JS (1997). What is a "heavy metal"? Journal of Chemical Education 74(11):1374. https://doi.org/10.1021/ed074p1374

$\mathrm{He} \mathrm{Z}$ (2006). Zinc compartmentation in root, transport into xylem, and absorption into leaf cells in the hyperaccumulating species of Sedum alfredii Hance. Planta 224:185-195. https://doi.org/10.1007/s00425005-0194-8

Hjortenkrans STD, Bergbäck GB, Häggerud VA (2007). Metal emissions from brake linings and tires: case studies of Stockholm, Sweden 1995/1998 and 2005. Environmental Science \& Technology 41(15):5224-5230. https://doi.org/10.1021/es070198o

Hooda SP (2010). Trace elements in soil. Kingston University London, A. John Wiley and Sons Ltd Blackwell Publishing, London.

Horner JM (1996). Environmental health implications of heavy metal pollution from car tires. Reviews on Environmental Health 11(4):175-8. https://doi.org/10.1515/reveh.1996.11.4.175 
Jaishankar M, Tseten T, Anbalagan N, Mathew BB, Beeregowda KN (2014). Toxicity, mechanism, and health effects of some heavy metals. Interdisciplinary Toxicology 7(2):60-72. https://doi.org/10.2478/intox-2014-0009

Jankowski K, Ciepiela GA, Jankowska J, Szulc W, Kolczarek R, Sosnowski J, ... Deska J (2015). Content of lead and cadmium in aboveground plant organs of grasses growing on the areas adjacent to route of big traffic. Environmental Science and Pollution Research 22(2):978-987. https://doi.org/10.1007/s11356-014-3634-9

Jaradat, QM, Momani KA (1999). Contamination of roadside soil, plants, and air with heavy metals in Jordan, a comparative study. Turkish Journal of Chemistry 23:209-220. https://journals.tubitak.gov.tr

Jarup L (2003). Hazards of heavy metal contamination. British Medical Bulletin 68(1):167-182. https://doi.org/10.1093/bmb/ldg032

Javorka S, Csapody V (1979). Iconographia Florae parties Austro-Orientalis Europae Centralis. Academiai Kido, Budapest.

Johanssona C, Norman M, Burman L (2009). Road traffic emission factors for heavy metals. Atmospheric Environment 43(31):4681-4688. https://doi.org/10.1016/j.atmosenv.2008.10.024

Josifović M (1970). Flora of Serbia I. SAAS, Beograd, pp 286-300.

Kabata-Pendias A (2001). Trace Elements in soil and plants. Boca Raton, CRC press (2nd ed), Washington, D.C.

Kabata-Pendias A (2011). Trace Elements in soil and plants. Boca Raton, CRC press (4th ed), Washington, D.C.

Kabata-Pendias A, Dudka (1991). Baseline data for cadmium and lead in soils and some cereals of Poland. Water, Air, \& Soil Pollution 57:723-731. https://doi.org/10.1007/BF00282936

Kabata-Pendias A, Mukherjee AB (2007). Trace elements from soil to human. Springer-Verlag Berlin Heidelberg.

Kandziora-Ciupa M, Ciepał R, Nadgórska-Socha A, Barczyk G (2013). A comparative study of heavy metal accumulation and antioxidant responses in Vaccinium myrtillus L. leaves in polluted and non-polluted areas. Environmental Science and Pollution Research 20:4920-4932. https://doi.org/10.1007/s11356-012-1461-4

Kastori R (1997). Teški metali u životnoj sredini [Heavy metals in environment]. Naučni institut za ratarstvo i povrtarstvo, Novi Sad.

Kumar JIN, Soni H, Kumar RN (2006). Biomonitoring of selected freshwater macrophytes to assess lake trace element contamination: a case study of Nal Sarovar Bird Sanctuary, Gujarat, India. The Journal of Limnology 65:9-16. https://doi.org/10.4081/jlimnol.2006.9

Laghlimi M, Baghdad B, El Hadi H, Bouabdli A (2015). Phytoremediation mechanisms of heavy metal contaminated soils: A Review. Open Journal of Ecology 5:375-388. http://dx.doi.org/10.4236/oje.2015.58031

Malinowska E, Jankowski K, Wiśniewska-Kadżajan B, Sosnowski J, Kolczarek R, Jankowska J, Grażyna A. Ciepiela (2015). Content of Zinc and Copper in selected plants growing along a motorway. Bulletin of Environmental Contamination and Toxicology 95:638-643. https://doi.org/10.1007/s00128-015-1648-8

Malizia D, Giuliano A, Ortaggi G, Masotti A (2012). Common plants as alternative analytical tools to monitor heavy metals in soil. Chemistry Central Journal 6(2):56. https://www.ncbi.nlm.nih.gov/pmc/articles/PMC3395142/

Markert B, Breure T, Zechmeister H (2003). Bioindicators and biomonitors - principles, concepts and applications. Amsterdam: Elsevier.

Marschner H (1995). Mineral nutrition of higher plants. UK: Academic Press, (2nd edn), London.

Mortvedt JJ, Giordano PM (1975). Response of corn to zinc and chromium in municipal wastes applied to soil. Journal of Environmental Quality 4(2):170-174. https://doi.org/10.2134/jeq1975.00472425000400020006x

Mullins GL, Sommers LE, Housley TL (1986). Metal speciation in xylem and phloem exudates. Plant Soil 96:377-391. https://doi.org/10.1007/BF02375142

Nagajyoti PC, Lee KD, Sreekanth TVM (2010). Heavy metals, occurrence and toxicity for plants: A Review. Environmental Chemistry Letters 8:199-216. https://doi.org/10.1007/s10311-010-0297-8

Oliveira H (2012). Chromium as an environmental pollutant: insights on induced plant toxicity. Journal of Botany 2012:1-8, Article ID 375843. https://doi.org/10.1155/2012/375843

Pais I, Jones JB (2000). The handbook of trace elements, St. Luice Press, Florida.

Pandy P, Tripathi K (2010). Bioaccumulation of heavy metal in soil and different plant parts of Albizia procera (Roxb.) seedling. The Bioscan 5(2):263-266. http://jmr.sharadpauri.org/papers/2010/2\%20Padney.pdf

Pavlović P, Mitrović M, Đorđević D, Sakan S, Slobodnik J, Liška I, Csanyi B, Jarić S, Kostić O, Pavlović D, Marinković N, Tubić B, Paunović M (2016). Assessment of the concentration of riparian soil and vegetation by trace metals A Danube river case study. Science of the Total Environment 540:396-409. https://doi.org/10.1016/j.scitotenv.2015.06.125 
Porebska G, Ostrowska A (1999). Heavy metal accumulation in wild plants: implications for phytoremediation. Polish Journal of Environmental Studies 8(6):433-442. https://pdfs.semanticscholar.org

Pravilnik o dozvoljenim količinama opasnih i štetnih materija u zemljištu i vodi za navodnjavanje i metodama njihovog ispitivanja [Regulations on permitted amounts of hazardous and harmful substances in soil and water for irrigation and methods of their testing]. Službeni glasnik RS, br. 23/94. http://www.podaci.net

Sawidis T, Breuste J, Mitrovic M, Pavlovic P, Tsigaridas K (2011). Trees as bioindicator of heavy metal pollution in three European cities. Environmental Pollution 159:3560-3570. https://doi.org/10.1016/j.envpol.2011.08.008

StatSoft, Inc. (2011). STATISTICA for Windows, version 10.0. Tulsa.

Susarla S, Medina VF, McCutcheon SC (2002). Phytoremediation, an ecological solution to organic contamination. Ecological engineering 18:647-658. https://doi.org/10.1016/S0168-1656(02)00218-3

Swaileh KM, Hussein RM, Abu-Elhaj S (2004). Assessment of heavy metal contamination in roadside surface soil and vegetation from the West Bank. Archives of Environmental Contamination and Toxicology 47:23-30. https://doi.org/10.1007/s00244-003-3045-2

Timothy N, Williams E T (2019). Environmental pollution by heavy metal: An Overview. International Journal of Environmental Chemistry 3(2):72-82. https://doi.org/10.11648/j.ijec.20190302.14

Tutin TG (1964-1980). Flora Europaea. In: Tutin T. G., Heywood V. H., Burges N. A., Valentine D. H., Walters S. M., Webb D. A. (Eds.). Cambridge University Press, Cambridge, United Kingdom.

Uredba o programu sistemskog praćena kvaliteta zemljišta, indikatorima za ocenu rizika od degradacije zemljišta i metodologiji za izradu remedijacionih programa [Regulation of the program accompanied by systematic soil quality, indicators for assessing the risk of soil degradation and methodology for development of remediation programs]. Službeni glasnik RS, br. 88/2010, prilog 3. http://www.sepa.gov.rs

Vamerali T, Bandiera M, Mosca G (2010). Field crops for phytoremediation of metal-contaminated land. A Review. Environmental Chemistry Letters 8:1-17. https://doi.org/10.1007/s10311-009-0268-0

White PJ (2001). The pathways of calcium movement to the xylem. Journal of Experimental Botany 52:891-899. https://doi.org/10.1093/jexbot/52.358.891

Weis JS, Weis P (2004). Metal uptake, transport and release by wetland plants: implications for phytoremediation and restoration. Environment International 30:685-700. https://doi.org/10.1016/j.envint.2003.11.002

Yoon J, Cao X, Zhou Q, Ma LQ (2006). Accumulation of Pb, Cu, and $\mathrm{Zn}$ in native plants growing on a contaminated Florida site. Science of the Total Environment 368:456-464. https://doi.org/10.1016/j.scitotenv.2006.01.016

Zacchini M, Pietrini F, Mugnozza, GS, Iori V, Pietrosan L, Massacci A (2009). Metal tolerance, accumulation and translocation in poplar and willow clones treated with cadmium in hydroponics. Water, Air, \& Soil Pollution 197:23-34. https://doi.org/10.1007/s11270-008-9788-7

Zeng F, Ali S, Zhang H, Ouyang Y, Qiu B, Wu F, Zhang G (2011). The influence of pH and organic matter content in paddy soil on heavy metal availability and their uptake by rice plants. Environmental Pollution 159(1):84-91. https://doi.org/10.1016/j.envpol.2010.09.019

Zhao GQ, Ma BL, Ren CZ (2007). Growth, gas exchange, chlorophyll fluorescence, and ion content of naked oat in response to salinity. Crop Science 47:123-131. https://doi.org/10.2135/cropsci2006.06.0371
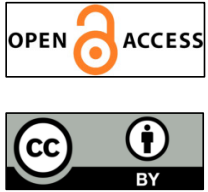

The journal offers free, immediate, and unrestricted access to peer-reviewed research and scholarly work. Users are allowed to read, download, copy, distribute, print, search, or link to the full texts of the articles, or use them for any other lawful purpose, without asking prior permission from the publisher or the author.

License - Articles published in Notulae Botanicae Horti Agrobotanici Cluj-Napoca are Open-Access, distributed under the terms and conditions of the Creative Commons Attribution (CC BY 4.0) License. (c) Articles by the authors; UASVM, Cluj-Napoca, Romania. The journal allows the author(s) to hold the copyright/to retain publishing rights without restriction. 